\title{
The High Middle Ages, edited by Kari E. Børresen and Adriana Valerio
}

The Bible and Women: An Encyclopedia of Exegesis and Cultural History, volume 6.2 | Atlanta: SBL Press, 201 5 | 468 pages | ISBN: 978-0-884-I 4049-8 (hardcover) £55.00

Part of The Bible and Women series, this volume emerged from a 2009 colloquium in Naples and explores female reception of the Bible in the twelfth

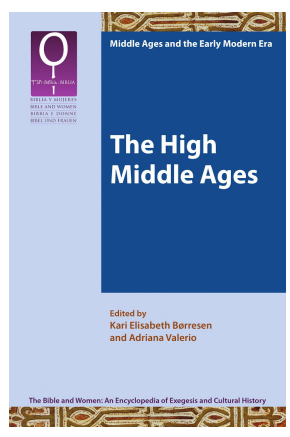
and thirteenth centuries, with themes extending to the sixteenth. Newly translated into English, this collection features articles by a geographically diverse set of specialists but is felicitously dominated by female scholarstwenty-one of twenty-three authors! - reinforcing its premise of engaging female voices in biblical interpretation. Twenty articles are divided into three parts, progressing from a general view of female communities interacting with the Bible, to specific female-authored texts, to female choices reflected in image and music. Per Adriana Valerio's introduction title, "The Bible in the Center," the Bible must be engaged critically as the heart of medieval spirituality. Though used as justification for the denigration of women, the Bible also granted women the vocabulary and authority to challenge limitations on their spiritual freedoms and practices. Tracing a cycle of repression of, and response by, religious women, this collection writes against the postGregorian view of femaleness as "incompatible with the sacred" (4) and its later conflation with witchcraft, instead seeking female agency in mysticism and the poverty movement.

Part I, "The Bible and Women: Reception and Application," identifies the interchange between medieval women, biblical verse, and persisting misogyny. In "The Treatment of Women in the Scriptural Commentaries of the Twelfth-Thirteenth Centuries," Gary Macy evaluates interpretations of Genesis and I Corinthians by five theologians. Juxtaposing the Ambrosiaster and Augustinian models, Macy tracks theological analysis and repercussions of the question of whether woman was made in the image of God or man. Focusing on Spain, María I. T. Pascua, in "The Bible and Women in Spanish Didactic-Moral Literature," collects examples of female biblical characters whom authors used as exemplars or warning tales for women of the Spanish 
courts, embedding familiar biblical tropes in commentaries on contemporary morality. In "Women Who Read the Bible in Spanish Kingdoms during the Middle Ages: Christians and Jews," Gemma Avenoza examines lay access to the Bible: in Jewish households, illiterate women heard vernacular recitations and memorized prayers, while literate Christian mothers gifted devotional texts to daughters, situating female exposure to the Bible in the domestic sphere.

The final two articles in this section explore the darker use of the Bible to disenfranchise marginalized women. In "The Bible, Women Heretics, and Inquisitors," Marina Benedetti considers the relationship between scripturein vernacular translations favored by Waldensians and Guglielmites-and the women who used knowledge of scripture to authorize their own charismatic preaching. In "Women, the Bible, and the Demonology of the Fifteenth Century," Dinora Corsi explores the Bible's "unintentional contribution" (I07) to the late medieval creation of the witch, tracking misogynistic rhetoric through the Malleus maleficarum and its critics.

Part 2, "Women and the Bible: Texts and Contexts," treats intellectual and mystical engagement with scripture. In section I, "Study and Creative Interpretations," Constant J. Mews and Carmel Posa explore "Heloise's Engagement with the Bible: A Continuing Journey," adding another facet to historical inquiry about the famous abbess. Educated in the convent's world of lectio divina, Heloise authoritatively used "biblical text as a mirror for her own life" (I 46). Direct contact with scripture helped her "reconcile the message of the Bible with the truth of her own experience" (I47), namely, a lifelong struggle with the "sin of finding pleasure in loving Abelard" (I32).

In "The Bible and Poetry: a Biblical Epic by a Woman (Ava) and a Biblical Epic about a Woman (Judith)," Magda Motté considers two twelfthcentury German texts whose authors display the "greatest confidence" (I63) in their thorough retellings of biblical narratives, which they actively reshaped to highlight female characters. Kari E. Børresen, in "Female Metaphors, From Scripture to Julian's Showings," reassesses the "bio-socio-culturally conditioned experience" ( 167 ) that frames interaction with God and credits Julian of Norwich with mending "Christianity's fundamental rift between Godhead and femaleness" ( 169 ). Rosa M. Parrinello sketches the role of educated women in the Eastern Empire in "Theodora Palaeologina and the Others: Women Scholars, Copyists, and Exegetes in Byzantium."

In Section 2, "Mysticism and Prophecy," Valeria F. Schiefer and Elisabeth Gössmann explore "Biblical Interpretations of the Work of Hildegard of 
Bingen (I098-1 179), ' illustrating Hildegard's use of scripture to undermine disparaging views of women. For example, her reading of Genesis recasts female "inferiority" as "privilege" (2 Io) by comparing Eve's ex carne creation from Adam to Christ's incarnation.

The next two articles envision the Bible as a timeless source of guidance for contemporary issues. Martina Kriedler-Kos discusses Clare of Assisi's application of scripture to daily life in "'Like Another Rachel, Always Remember Your Resolution and Be Conscious of How You Began': Clare of Assisi and the Bible." Despite lacking a copy of the Bible due to vows of poverty, Clare confidently incorporated scriptural themes, like the Sermon on the Mount and the mystical bride motif, into her own immediate concernseven finding endorsement of poverty in the Virgin's choice to give birth in a manger! In "The Bible as Center of Innovative God-Language in Mechthild of Magdeburg and Gertrude of Helfta," Hildegund Keul considers the vernacular Bible's continuing relevancy and renewability for these two mystics who tuned scriptural messages to address concerns about pursuing poverty in a corruptive money economy.

In the context of the Avignon Papacy, Børresen examines "Scripture in Birgitta's Revelations." Birgitta Birgersdotter's self-proclaimed status as a divine medium aligned with her Mariocentric interpretation of salvation history, centered around women who bore "fully godlike equivalence with men" (265). Rita Librandi explores the "Style and Translation of the Biblical Citations in the Letters of Catherine of Siena," closely reading scriptural references alongside Catherine's rephrasing of them in her exhortatory Letters. In similarly chaotic climates, Maria L. Giordano sketches the converso experience in fifteenth-century Spain in “'The Wolf Shall Live with the Lamb' (Isa I I:6): The Defeat of a Converso Utopia in the Work of Teresa de Cartagena (I 449-I 478)." By developing biblical models like the value of suffering, the language of a "chosen people," and the story of Job, Teresa sought unsuccessfully to extend her "literature of coexistence" (286) into the political sphere to empower conversos facing expulsion and Inquisition.

Part 3, "Representation in the Arts," locates female voices in imagery and music. Andrea Taschl-Erber, in "Apostle and Sinner: Medieval Receptions of Mary of Magdala," untangles the identity of Mary of Magdala from the medieval composite figure of Mary Magdalene, stressing her roles as first witness to the Resurrection and Apostola apostolorum, and emphasizing her iconographic depiction as a teacher as a corrective to Pauline restrictions on female preaching. 
The second and third articles evaluate the moralistic treatise Hortus Deliciarum, "composed by women, for women, and physically realized by women" (329), peeking behind cloister walls to glimpse reception and interpretation of the Bible. In "The Image of Women and Narrative Strategies in the Hortus Deliciarum," Paola Vitolo considers the program of illumination as a meaningful counterpoint to the text, showcasing the agency of female "protagonists" (334) as models to its audience of nuns. In "The Bible in the Hortus Deliciarum," Claudia Poggi and Marina Santini identify the use of biblical women as exempla intended to prepare readers for mystical union with Christ.

In "Women, the Bible, and Music in the Middle Ages," Linda M. Koldau situates female musical culture in liturgical song. Invoking Hildegard of Bingen's "inseparable connection of theology and music" (367), Koldau shows how deeply medieval nuns internalized biblical words rendered as music. In "Women and the Bible: Iconography of a Relationship in the Lower Middle Ages," María L. S. Hernández uses library collections, religious devotional cards, and stained glass to track cultural literacy among nuns, aristocratic women, and the illiterate.

Scholars seeking commentary on particular books of the Bible will enjoy the Index of Ancient Sources (445). Within the volume, discrepancies and typographical errors affected the readability of otherwise lucid English translations. Most importantly, for a reader-friendly work, longer or unfamiliar Latin and Greek passages should be translated. Throughout, originallanguage and translated lines were inconsistently italicized and ordered, and recognizable English names were not standardized. Occasional but noticeable errors appeared throughout: "Valdes of Lyon of Lyon" (88); "eigthy three" (I 88); "Annunciation" (39I) but "annunciation" (398); missing end quotations (I 87); etc. Though minor, such discrepancies interrupt the harmony of the multi-authored work. This volume contributes to scholarly understanding of medieval women's access to and reception of the Bible by revealing eager absorption despite restrictions of gender, status, or literacy. An underscoring feminist perspective helpfully encourages readers to reevaluate models taken for granted — such as Hildegard's elegant challenge to the idea that Eve's creation from Adam subordinated her. In some places, however, an interest in emphasizing female contributions overreaches the argument: for example, Julian of Norwich's “innovative God-language” (I72) was presented without connection to Cistercian models that shaped the use of feminized mystical language. The articles by Motté, Schiefer and Gössmann, 
Kriedler-Kos, and Librandi, in particular, cogently advance our understanding of female reception of scripture by providing concrete linguistic evidence of internalization and creative use of biblical texts. In the wake of historiographical focus on exceptional female religiosity, this collection restores the centrality of the universal biblical text as a common language among heretics and saints alike. In sum, the collection shines a still-needed light on the various sources and voices of medieval women who encountered, embraced, and received the Bible into their work and lives.

Christine Axen

Plymouth State University 